\title{
ДОСЛІДЖЕННЯ ВПЛИВУ КІЛЬКІСНИХ ФАКТОРІВ НА ФАРМАКО-ТЕХНОЛОГІЧНІ ВЛАСТИВОСТІ ПОРОШКОВИХ МАС ТА ТАБЛЕТОК ЕКСТРАКТУ ГРУШАНКИ КРУглОлИстої
}

\author{
СН. П. Дарзулі, Т. А. Грошовий \\ ДВНЗ «Тернопільський державний медичний університет імені І. Я. Горбачевського \\ мОЗ України» \\ darzulinp@tdmu.edu.ua
}

\begin{abstract}
Мета роботи. Дослідження впливу кількісних факторів на фрармако-технологічні властивості порошкових мас та таблеток на основі сухого екстракту грушанки круглолистої.

Матеріали і методи. Вивчення впливу 7-ми кількісних фракторів на властивості мас для таблетування і основні показники якості таблеток екстракту листя грушанки круглолистої проводили використовуючи метод випадкового балансу. Вивчали такі показники якості порошкових сумішей та талеток на їх основі: текучість, вільну насипну густину, насипну густину після усадки, індекс Кара, зовнішній вигляд, однорідність маси, розпадання, стійкість до роздавлювання, стираність, срункція бажаності.

Результати й обговорення. Дослідження, проведені з використаннням методу випадкового балансу, показали, що найбільшою мірою текучість порошкової суміші залежала від кількості фрловлаксу: із її збільшенням таблетна маса витікала швидше та неусиліну US 2, магнію стеарату, при збільшені яких текучість зменшується.

При зменшенні кількості неусиліну US 2 у складі таблетки відхилення від середньої маси знижувалося. Із додаванням у таблетки екстракту листя грушанки круглолистої більшої кількості натрій карбоксиметилкрохмалю, таблетози 80 та магнію стеарату значення даного показника покращувалося.

Найбільш суттєво на стійкість до роздавлювання таблеток екстракту листя грушанки круглолистої впливало зменшення кількості таблетози 80, в результаті чого таблетки ставали міцніші.

Найбільший вплив на стираність таблеток екстракту листя грушанки круглолистої мала кількість натрій кроскармелози, із збільшенням якої показник зростав.

При дослідженні розпадання таблеток екстракту листя грушанки круглолистої встановлено, що зменшення кількості неусиліну US 2, PROSOLV® EASYtab SP та магнію стеарату у складі таблеток покращували їх розпадання.

Висновки. Встановлено вплив кількості допоміжних речовин на фрармако-технологічні показники якості таблетних мас і таблеток із екстрактом грушанки круглолистої. У процесі досліджень використано функцію бажаності як узагальнений показник якості порошкових сумішей та таблеток. Результати досліджень дозволили відібрати такі речовини для подальших досліджень: неусилін US 2, PROSOLV® EASYtab SP, натрій кроскармелозу, таблетозу 80 та магнію стеарат.
\end{abstract}

Ключові слова: таблетки; фрармако-технологічні показники порошкових мас; рослинні екстракти; грушанка круглолиста; математичне планування експерименту.

Вступ. Розробка технології таблеток на основі рослинних екстрактів вимагає прийняття оптимальних рішень щодо вибору технологічних прийомів та природи допоміжних речовин (ДР), які будуть використані. Рослинні екстракти володіють незадовільними фрармако-технологічними властивостями, тому метод одержання таблеток обирають особливо ретельно [1]. Сьогодні ринок налічує близко 6000 найменувань сучасних ДР, що дозволяє змінити підходи до розробки технології таблеток, в склад яких входять АФІ 3 незадовільними фрармако-технологічними властивостями [2, 3]. При раціональному використанні ДР можна забезпечити відмінні фрармако-технологічні властивості порошкових сумішей та в подаль- шому забезпечити якість таблеток згідно з вимогами ДФУ, що дозволить використати пряме пресування як метод одержання таблеток у багатьох випадках [4].

Попередні дослідження дозволили вивчити вплив 27 ДР на фрармако-технологічні властивості порошкових сумішей та таблеток з екстрактом грушанки круглолистої. В результаті експерименту відібрано найкращі ДР із кожної вивченої групи [5].

Мета роботи - вивчити вплив кількісних фракторів на фрармако-технологічні властивості порошкових мас для таблетування та таблеток із сухим екстрактом грушанки круглолистої методом прямого пресування.

Матеріали і методи. Враховуючи результати попередніх досліджень, отриманих за допомогою дис- 
Фармацевтична технологія, біофармація, гомеопатія Pharmaceutical technology, biopharmacy, homeopathy

персійного аналізу та фрункції бажаності, для подальших досліджень відібрано кращі ДР, які вивчали на нижньому та верхньому рівнях.

Вивчення впливу кількісних фракторів на властивості мас для таблетування та основні показники якості таблеток екстракту листя грушанки круглолистої проводили використовуючи метод випадкового балансу [6]. Даний метод дозволяє дібрати певні ДР в оптимальній кількості та відкинути ті ДР, які не забезпечують фрармако-технологічні показники якості таблеток повною мірою. Кількісні фрактори та їх рівні наведено в таблиці 1.

Враховуючи план експерименту, готували порошкові суміші за класичною схемою приготування порошків та досліджували технологічні властивості сумішей та таблеток на їх основі, а саме: текучість, вільну насипну густину, насипну густину після усадки, індекс Кара, зовнішній вигляд, однорідність маси, розпадання, міцність, стираність, фрункцію бажаності [7].

План і результати дослідження таблеток екстракту листя грушанки круглолистої наведено в таблиці 2.

Результати й обговорення. На основі статистичної обробки одержаних результатів будували рисунки і за величиною медіани встановлювали вплив досліджуваного фрактора на вивчений показник. Напрямок орієнтування медіани показував, в яку сторону спрямований цей вплив.

Найбільшою мірою текучість порошкової суміші залежала від кількості фрловлаксу: із їі збільшенням таблетна маса витікала швидше; неусиліну US 2 і магнію стеарату, при збільшені яких текучість зменшувалась (рис. 1). Решта фракторів мала менший вплив на досліджуваний відгук. Так, із збільшенням кількості PROSOLV ${ }^{\circledR}$ EASYtab SP текучість порошкової суміші погіршувалася. Із збільшенням кількості натрій кроскармелози, натрію карбоксиметилкрохмалю та таблетози 80 текучість порошкової суміші зростала.

Аналізуючи одержані результати щодо вільної насипної густини порошкових мас з екстрактом листя грушанки круглолистої, значення досліджуваного показника зростало із збільшенням кількості натрію карбоксиметилкрохмалю, срловлаксу та таблетози 80 в їх складі. Збільшення кількості неусиліну US 2 та магнію стеарату призводило до зниження показника вільної насипної густини. Вплив кількості PROSOLV® EASYtab SP та кількості натрій кроскармелози в межах вивчених інтервалів був незначущим.

Насипна густина після усадки порошкових мас 3 екстрактом листя грушанки круглолистої найбільшою мірою залежала від кількості неусиліну US 2 та таб-

Таблиця 1. Фактори та їх рівні, які вивчали при розробці складу таблеток екстракту листя грушанки круглолистої

\begin{tabular}{|c|c|c|c|}
\hline \multirow{2}{*}{ Фактори } & \multicolumn{3}{|c|}{ Рівні фракторів } \\
\hline & нижній «-» & основний «0» & верхній «+» \\
\hline х & 4,0 & 5,0 & 6,0 \\
\hline $\mathrm{x}_{2}$ - кількість PROSOLV® EASYtab SP, \% & 12,0 & 15,0 & 18,0 \\
\hline x & 2,0 & 3,0 & 4,0 \\
\hline x - кількість натрію карбоксиметилкрохмалю, \% & 2,0 & 3,0 & 4,0 \\
\hline х & 4,5 & 3,0 & 8,5 \\
\hline х & 4,5 & 3,0 & 8,5 \\
\hline x 7 - кількість магнію стеарату, \% & 0,0 & 0,5 & 1,0 \\
\hline
\end{tabular}

Таблиця 2. Матриця планування експерименту методом випадкового балансу та результати дослідження порошкових мас і таблеток грушанки круглолистої

\begin{tabular}{|c|c|c|c|c|c|c|c|c|c|c|c|c|c|c|c|c|c|}
\hline $\begin{array}{c}\text { Homep } \\
\text { cepiï }\end{array}$ & $\mathrm{x}_{1}$ & $\mathrm{x}_{2}$ & $\mathrm{x}_{3}$ & $\mathrm{x}_{4}$ & $\mathrm{x}_{5}$ & $\mathrm{x}_{6}$ & $\mathrm{x}_{7}$ & $\mathrm{y}_{1}$ & $\mathrm{y}_{2}$ & $\mathrm{y}_{3}$ & $\mathrm{y}_{4}$ & $\mathrm{y}_{5}$ & $\mathrm{y}_{6}$ & $\mathrm{y}_{7}$ & $\mathrm{y}_{8}$ & $\mathrm{y}_{9}$ & $\mathrm{D}$ \\
\hline 1 & - & - & - & + & + & + & - & 25,56 & 0,60 & 0,72 & 16,67 & 4 & 1,61 & 13 & 186,4 & 0,1331 & 0,78 \\
\hline 2 & - & + & - & + & - & + & + & 27,78 & 0,58 & 0,75 & 22,67 & 4,5 & 2,13 & 16,5 & 196,2 & 0,1166 & 0,49 \\
\hline 3 & + & - & - & - & - & - & + & 30,83 & 0,55 & 0,69 & 20,30 & 5 & 2,27 & 18 & 199,9 & 0,1496 & 0,3 \\
\hline 4 & + & + & - & - & + & - & - & 27,56 & 0,56 & 0,67 & 16,42 & 4 & 2,71 & 17 & 196,4 & 0,1331 & 0,37 \\
\hline 5 & - & - & + & + & - & - & + & 26,89 & 0,58 & 0,75 & 22,67 & 4,5 & 1,79 & 14 & 194,3 & 0,1664 & 0,73 \\
\hline 6 & - & + & + & - & + & + & - & 24,83 & 0,60 & 0,75 & 20 & 4,5 & 2,15 & 13,5 & 191,4 & 0,1661 & 0,76 \\
\hline 7 & + & - & + & + & + & - & - & 26,89 & 0,56 & 0,69 & 18,84 & 4 & 3,71 & 12 & 196,5 & 0,1666 & 0,61 \\
\hline 8 & + & + & + & - & - & + & + & 29,27 & 0,56 & 0,72 & 22,22 & 5 & 2,90 & 15 & 185,2 & 0,1331 & 0,60 \\
\hline
\end{tabular}

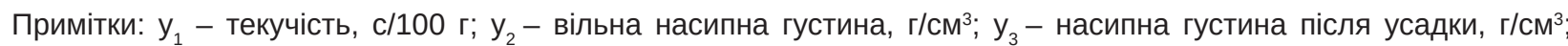
$\mathrm{y}_{4}$ - індекс Кара, \%; $\mathrm{y}_{5}-$ зовнішній вигляд, бал; $\mathrm{y}_{6}-$ однорідність маси, $\pm \% ; \mathrm{y}_{7}-$ розпадання, хв; $\mathrm{y}_{8}-$ міцність, Н; $\mathrm{y}_{9}$ - стираність, \%; D - фрункція бажаності.

ISSN 2312-0967. Фармацевтичний часопис. 2018. № 3 
Фармацевтична технологія, біофармація, гомеопатія Pharmaceutical technology, biopharmacy, homeopathy

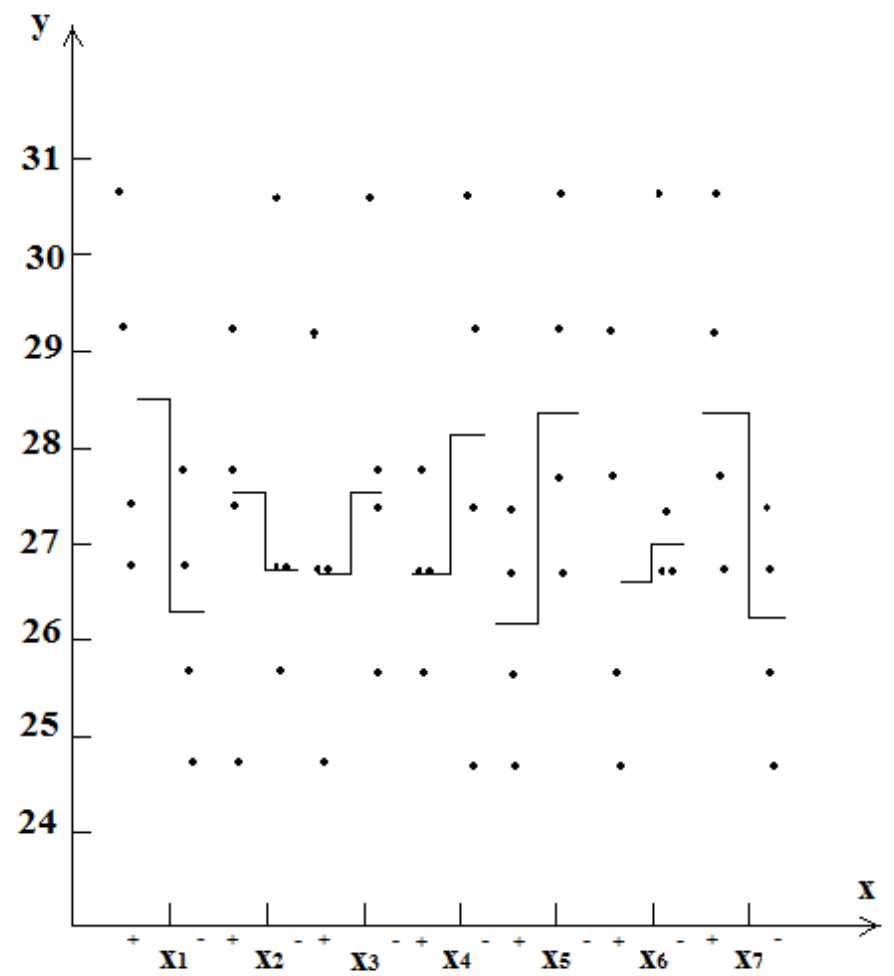

Рис. 1. Діаграма розсіювання результатів дослідження текучості порошків з екстрактом листя грушанки круглолистої.

летози 80 у їх складі, із зменшенням їх кількості показник насипної густини після усадки підвищувався.

Із збільшенням кількості PROSOLV® EASYtab SP, натрій кроскармелози, натрію карбоксиметилкрохмалю, магнію стеарату зростала насипна густина порошкових мас, а при збільшенні кількості фрловлаксу - значення даного показника зменшувалося.

Результати дослідження індексу Кара показали, що значно впливали на даний показник кількість фрловлаксу, при збільшені якого показник зменшувався та кількість магнію стеарату при збільшені - показник погіршувався. Решта фракторів мала менший вплив на досліджуваний відгук. Зменшення PROSOLV® EASYtab SP, натрію кроскармелози, натрій карбоксиметилкрохмалю та таблетози 80 та збільшення неусиліну US 2 призводили до покращення показників індексу Кара.

Згідно з одержаними результатами встановлено, що всі серії порошкових мас екстракту листя грушанки круглолистої пресувалися добре, в результаті пресування отримували таблетки, які відповідали всім визначеним критеріям щодо зовнішнього вигляду.

Найбільший вплив на однорідність дозування має кількість неусиліну US 2 (рис. 2). При зменшенні кількості неусиліну US 2 у складі таблетки відхилення від середньої маси знижувалося. Із додаванням в таблетки екстракту листя грушанки круглолистої більшої кількості натрій карбоксиметилкрохмалю, таблетози 80 та магнію стеарату значення даного показника по- кращувалося. Збільшення кількості PROSOLV® EASYtab SP, натрій кроскармелози та фрловлаксу погіршувало даний показник.

Найбільш суттєво на стійкість до роздавлювання таблеток екстракту листя грушанки круглолистої впливало зменшення кількості таблетози 80, в результаті чого таблетки ставали міцнішими. Також зі зменшенням кількості PROSOLV® EASYtab $\mathrm{SP}$, натрій кроскармелози та фрловлаксу та збільшенням кількості неусіліну US 2, натрій карбоксиметилкрохмалю, магнію стеарату таблетки ставали міцнішими

Найбільший вплив на стираність таблеток екстракту листя грушанки круглолистої мала кількість натрій кроскармелози, із збільшенням якої показник зростав. Решта фракторів мала менший вплив на досліджуваний відгук. Так, стираність таблеток зменшувалась із додаванням у їх склад більшої кількості неусіліну US 2, PROSOLV® EASYtab SP, таблетози 80, магнію стеарату. Збільшення кількості натрій карбоксиметилкрохмалю та фрловлаксу призводили до погіршення показника стираності таблеток.

При дослідженні розпадання таблеток екстракту листя грушанки круглолистої встановлено, що зменшення кількості неусиліну US 2, PROSOLV® EASYtab SP та магнію стеарату у складі таблеток покращувало їх розпадання. Зменшення кількості натрій кроскармелози, натрій карбоксиметилкрохмалю, фрловлаксу, таблетози 80 погіршувало процес розпадання таблеток з екстрактом грушанки круглолистої.

ISSN 2312-0967. Pharmaceutical review. 2018. № 3 
Фармацевтична технологія, біофармація, гомеопатія

Pharmaceutical technology, biopharmacy, homeopathy

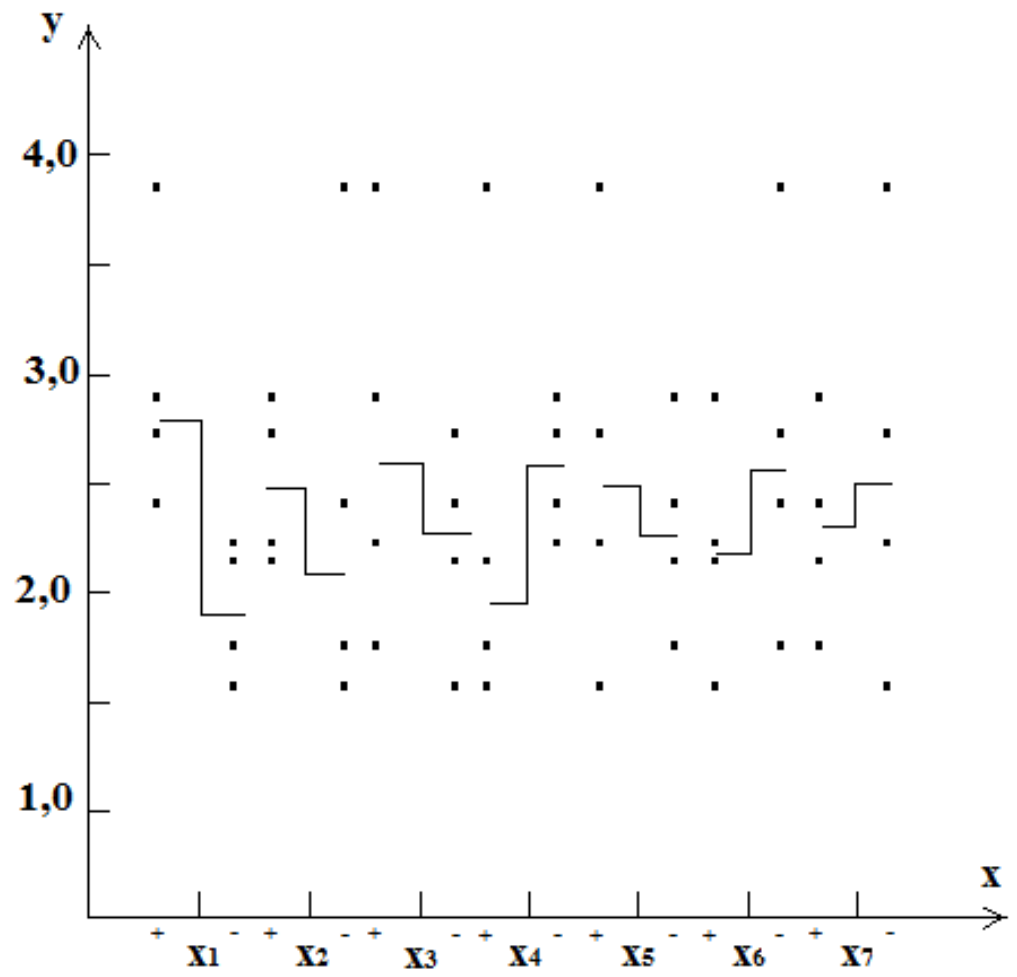

Рис. 2. Діаграма розсіювання результатів дослідження однорідності маси таблеток екстракту листя грушанки круглолистої.

Для узагальнення показників одержані результати переводили в безрозмірні величини за допомогою функції бажаності і на їх основі будували медіани (рис. 3). За величиною і напрямком медіан встановлювали вплив досліджуваних кількісних фракторів на узагальнений показник.

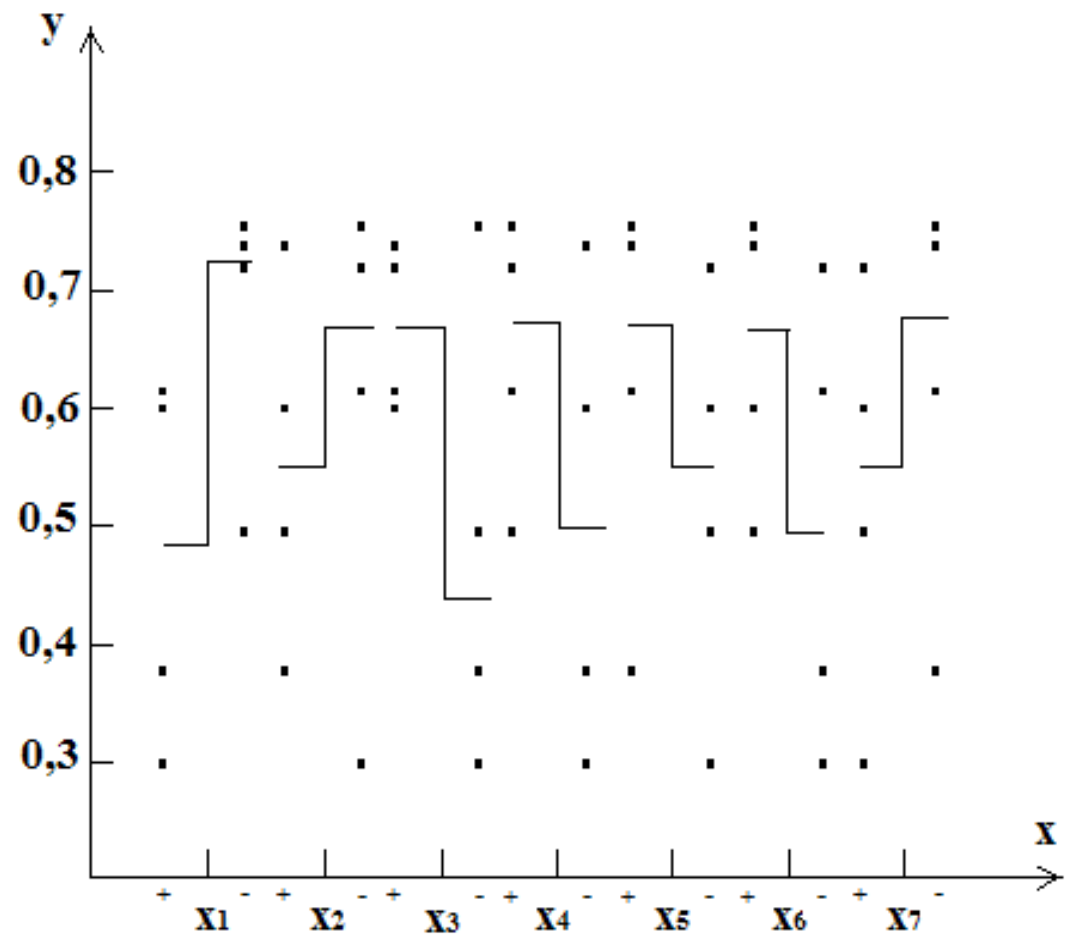

Рис. 3. Діаграма розсіювання результатів дослідження впливу кількісних фракторів на узагальнений показник.

ISSN 2312-0967. Фармацевтичний часопис. 2018. № 3 
Фармацевтична технологія, біофармація, гомеопатія

Pharmaceutical technology, biopharmacy, homeopathy

При вивченні довжини та орієнтування медіан встановлено, що значно впливали на більшість вивчених показників якості таблеток екстракту листя грушанки круглолистої кількість неусиліну та натрію кроскармелози. Кращий ефект при цьому спостерігали при використанні неусиліну US 2 на нижньому рівні, а натрій кроскармелози на верхньому рівні.

Погіршення узагальненого показника таблеток екстракту листя грушанки круглолистої спостерігалось із збільшенням кількості PROSOLV® EASYtab SP та магнію стеарату. При вивченні кількості натрій кроскармелози та натрій карбоксиметилкрохмалю встановлено, що покращення узагальненого показнику відбувається при збільшені кількостей ДР, і збільшення кількості натрій кроскармелози чинить більший вплив на функцію бажаності.
При вивченні кількості фрловлаксу та таблетози 80 встановлено, що покращення узагальненого показника відбувається при збільшені кількостей ДР, і збільшення кількості таблетози 80 чинить більший вплив на узагальнений показник якості таблеток.

Висновки. Встановлено вплив кількості допоміжних речовин на фрармако-технологічні показники якості таблетних мас і таблеток з екстрактом грушанки круглолистої. В процесі досліджень використано фрункцію бажаності як узагальнений показник якості порошкових сумішей та таблеток. Результати досліджень дозволили відібрати такі речовини для подальших досліджень: неусилін US 2, PROSOLV® EASYtab SP, натрій кроскармелозу, таблетозу 80 та магнію стеарат.

\title{
ИССЛЕДОВАНИЕ ВЛИЯНИЯ КОЛИЧЕСТВЕННЫХ ФАКТОРОВ НА ФАРМАКО-ТЕХНОЛОГИЧЕСКИЕ СВОЙСТВА ПОРОШКОВЫХ МАС И ТАБЛЕТОК ЭКСТРАКТА ГРУШАНКИ КРУГЛОЛИСТНОЙ
}

\author{
Н. П. Дарзули, Т. А. Грошовый \\ ГВУз «Тернопольский государственный медицинский университет имени И. Я. Горбачевского Мз \\ Украины» \\ darzulinp@tdmu.edu.ua
}

Цель работы. Исследование влияния количественных фракторов на фрармако-технологические свойства порошковых масс и таблеток на основе сухого экстракта грушанки круглолистной.

Материалы и методы. Изучение влияния 7-ми количественных фракторов на свойства масс для таблетирования и основные показатели качества таблеток экстракта листьев грушанки круглолистной проводили используя метод случайного баланса. Изучали следующие показатели качества порошковых смесей и таблеток на их основе: текучесть, свободную насыпную плотность, насыпную плотность после усадки, индекс Кара, внешний вид, однородность массы, распад, устойчивость к раздавливанию, истираемость, функция желательности.

Результаты и обсуждение. Исследования проведены с использованием метода случайного баланса показали, что в наибольшей степени текучесть порошковой смеси зависела от количества фрловлакса: с ее увеличением таблетная масса вытекала быстрее и неусилина US 2, магния стеарата, при увеличении которых текучесть уменьшается.

При уменьшении количества неусилина US 2 в составе таблетки отклонения от средней массы снижалось. С добавлением в таблетки экстракта листьев грушанки круглолистной больших количеств натрий карбоксиметилкрахмала, таблетозы 80 и магния стеарата значение данного показателя улучшалось.

Наиболее существенно на устойчивость к раздавливанию таблеток экстракта листьев грушанки круглолистной влияло уменьшение количества таблетозы 80, в результате чего таблетки становились крепче.

Наибольшее влияние на истираемость таблеток экстракта листьев грушанки круглолистной имело количество натрия кроскармеллозы, с увеличением которой показатель увеличивался.

При исследовании распада таблеток экстракта листьев грушанки круглолистной установлено, что уменьшение количества неусилина US 2, PROSOLV® EASYtab SP и магния стеарата в составе таблеток улучшали их распад.

Выводы. Установлено влияние количеств вспомогательных веществ на фрармако-технологические показатели качества таблетных масс и таблеток с экстрактом грушанки круглолистной. В процессе исследований использовали фуункцию желательности как обобщенный показатель качества порошковых смесей и таблеток. Результаты исследований позволили отобрать следующие вещества для дальнейших исследований: неусилин US 2 , PROSOLV® EASYtab SP, натрий кроскармеллоза, таблетоза 80 и магнию стеарат.

Ключевые слова: таблетки; фрармако-технологические показатели порошковых масс; растительные экстракты; грушанка круглолистная; математическое планирование эксперимента.

ISSN 2312-0967. Pharmaceutical review. 2018. № 3 
Фармацевтична технологія, біофармація, гомеопатія

Pharmaceutical technology, biopharmacy, homeopathy

\title{
STUDY OF QUANTITATIVE FACTORS ON TECHNOLOGICAL PROPERTIES OF COMPRESSION MIXTURE AND TABLETS OF ROUND-LEAVED WINTERGREEN EXTRACT
}

\author{
N. P. Darzuli, T. A. Hroshovyi \\ I. Horbachevsky Ternopil State Medical University \\ darzulinp@tdmu.edu.ua
}

The aim of the work. Investigation of the influence of quantitative factors on the pharmacological and technological properties of compression mixture and tablets on the basis of dry extract from round-leaved wintergreen.

Materials and Methods. The study of the influence of 7 quantitative factors on the properties of compression mixture and the tablets of round-leaved wintergreen leaf were carried out using the random balance method. The following indicators of quality of compression mixture and tablets were studied: flowability, free bulk density, bulk density after shrinkage, Kara index, appearance, mass homogeneity, disintigration, resistance to crushing tablets, friability, desirability function.

Results and Discussion. Studies conducted using the method of random balance showed that to a large extent, the fluidity of the compression mixture depended on the amount of flovlacs: with its increase, the tablet mass flowed faster and neusilin US 2, magnesium stearate, with increasing the flow of which decreases.

When decreasing the amount of neusilin US 2 in the tablet, the deviation from the average mass declined. With the addition of from round-leaved wintergreen extracts, large amounts of sodium carboxymethylstarch, tabletose 80 and magnesium stearate, the value of this indicator improved.

The most significant effect on resistance to crushing tablets was the decrease in the number of tabletose 80 , which resulted in the tablets becoming stronger

The greatest influence on the friability of the tablets, with a small amount of sodium croscarmellose, with the increase of which the index has increased.

In the study of the disintigration of tablets, it was found that a decrease in the number of neusilin US2, prosolv EASY tab $\mathrm{SP}$, and magnesium stearate in tablets led to a reduction in their disintigration.

Conclusions. The influence of the amounts of substances on the technological indicators of the quality of compression mixture and the tablets with round-leaved wintergreen extract was determined. In the process of research, the function of desirability, as a generalized indicator of the quality of compression mixture and tablets, has been used. The results of the studies allowed selecting the following excipients for further research: neusilin US 2, prosolv EASY tab SP, sodium croscarmellose, tabletose 80 and magnesium stearate.

Key words: tablet; technological parameters compression mixture; vegetable extracts; pyrola rotundifolia; round-leaved wintergreen; mathematical planning of the experiment.

\section{Список літератури}

1. Шостак Т. А. Особливості фрармацевтичної розробки рослинних препаратів / Т. А. Шостак, Т. Г. Калинюк, Н. І. Гудзь // Фармацевтичний часопис. - 2014. - № 4. - С. 77-82.

2. Аутлов С. А. Микрокристаллическая целлюлоза: структура, свойства и области применения (обзор) С. А. Аутлов, Н. Г. Базарнова, Е. Ю. Кушнир // Химия растительного сырья. 2013. №3. С. 33-41.

3. Beley S. Ya. Investigation of the pharmaceutical factors influence on technological properties of the compression mixture and some quality indicators of tablets based on Malva sylvestris L. and Plantago lanceolata L. dry extracts / S. Ya. Beley, T. A. Hroshovyi, N. M. Beley // Pharmaceutical review. - 2017. - No. 4. - P. 41-49.

4. Допоміжні речовини в виробництві ліків : навч. посіб. для студ. вищ. фрармац. навч. закл. / О. А. Рубан, І. А. Перцев, Д. І. Дмитрієвський та ін. ; за ред. І. А. Пер- цева. - Х. : Золоті сторінки. - 2016. - 720 с.

5 . Investigation of the effects of excipients on technological properties tablets of round-leaved wintergreen extract. / N. Darzuli, T. Hroshovyi, K. Sokolova, E. Podpletnyaya // Scientific Journal "ScienceRise: Pharmaceutical Science". - 2018. - No. 2. - P. 43-48.

6. Математичне планування експерименту при проведенні наукових досліджень в фрармації / [Т. А. Грошовий, В. П. Марценюк, Л. І. Кучеренко та ін.]. - Тернопіль : Укрмедкнига, 2008. - 367 с

7. Державна Фармакопея України: в 3 т. / Державне підприємство «Український науковий фрармакопейний центр якості лікарських засобів». - 2е вид. - Харків : Державне підприємство «Український науковий орармакопейний центр якості лікарських засобів», 2015. - T. 1. -1128 c.

\section{References}

1. Shostak TA, Kalyniuk TH, Hudz NI. [Features of pharmaceutical development of plant drugs]. Farmatsevt chasop. 2014;4: 77-82. Ukrainian.

2. Outlov SA, Bazarnova NG, Kushnir EYu. [Microcrystalline cellulose: structure, properties and applications]. Khimiya rast syrya. 2013;3: 33-41. Russian.

ISSN 2312-0967. Фармацевтичний часопис. 2018. № 3 
3. Beley SYa, Hroshovyi TA, Beley NM. Investigation of the pharmaceutical factors influence on technological properties of the compression mixture and some quality indicators of tablets based on Malva sylvestris L. and Plantago lanceolata L. dry extracts. Pharmaceutical review 2017;4: 41-9.

4. Ruban OA, Pertsev IA, Dmytriievskyi DI, Rybachuk VD. Excipients in the manufacture of drugs. [Допоміжні речовини в виробництві ліків] Kharkiv: Zoloti storinky 2016. Ukrainian.

5. Darzuli NP, Hroshovyi TA, Sokolova KV, Podpletnyaya EA Investigation of the effects of excipients on technological
Фармацевтична технологія, біофармація, гомеопатія Pharmaceutical technology, biopharmacy, homeopathy properties tablets of round-leaved wintergreen extract. Scientific Journal "ScienceRise: Pharmaceutical Science". 2018;2: 43-8.

6. Hroshovyi TA, Martseniuk VP, Kucherenko LI, Vronska LV, Hurieieva SM. Mathematical planning of experiment in pharmacy. [Математичне планування експерименту в формації] Ternopil: Ternopil State Medical University; 2008. Ukrainian.

7. State Pharmacopoeia of Ukraine. [Державна Фармакопея України: в 3 т.,2е вид.] Kharkiv: State Enterprise: Ukrainian Scientific Pharmacopoeia Center for the Quality of Medicines; 2015. Ukrainian.

Отримано 30.04.2018 